JURNAL SPORTIF
Pendidikan Jasmani, Kesehatan dan Rekreasi
Volume 5, No. 1, 2020
http://jurnal.stkipbanten.ac.id/index.php/sportif

\title{
PENGGUNAAN METODE DEMONSTRASI TERHADAP KETEPATAN MENENDANG MENGGUNAKAN PUNGGUNG KAKI PADA PERMAINAN SEPAK BOLA
}

\author{
Bayan Ardana Wikarta ${ }^{1}$, Jamaludin ${ }^{2}$ \\ ${ }^{1}$ Sekolah Tinggi Keguruan dan Ilmu Pendidikan Banten \\ ${ }^{2}$ Mahasiswa Pendidikan Jasmani kesehatan dan Rekreasi \\ ․ㅣㄹayanardana22@gmail.com, ${ }^{2}$ jamaludin721@gmail.com
}

\begin{abstract}
ABSTRAK
Penelitian ini bertujuan untuk mengetahui Pengaruh Metode Demonstrasi Terhadap Ketepatan Menendang Menggunakan Punggung Kaki Pada Permainan Sepak Bola, teknik pengumpulan data menggunakan metode literatur yaitu cara mengumpulkan data dari berbagai sumbersumber seperti buku-buku, jurnal, artikel dan penelitian terdahulu. Metode demonsrtrasi adalah metode peragaan atau memperagakan mengenai suatu kejadian. Sepak bola adalah cabang olahraga beregu yang dimainkan oleh dua regu yang berhadapan, bola dimainkan dengan cara di tendang. Salah satu teknik individu yang harus dikuasi pemain sepak bola adalah teknik dasar menendang. Menendang dilakukan untuk melakukan operan dan melakukan tendangan ke arah gawang. Hasil dari berbagai sumber yang telah di analisa, metode demonstrasi dapat memberikan pengaruh yang signifikan dalam proses pembelajaran, metode demonstrasi memberikan peningkatan terhadap keterampilan menendang sepak bola peserta didik. Dari hasil penelitian dapat disimpulkan bahwa metode demonstrasi dapat memberikan pengaruh dan dapat meningkatkan kemampuan peserta didik dalam permainan sepak bola.
\end{abstract}

Kata Kunci: Metode Demonstrasi, Punggung Kaki, Permainan Sepak bola 


\section{PENDAHULUAN}

Dalam proses pendidikan disekolah, kegiatan belajar merupakan kegiatan yang paling pokok. Proses belajar disekolah tidak hanya dilakukan peserta didik didalam jam belajar kurikulum standart,tetapi juga dapat dilakukan diluar jam belajar kurikulum standart. Kegiatan ini ada pada setiap jenjang disekolah dasar sampai perguruan tinggi. Kegiatan proses belajar terjadi malalui interaksi aktif antara peserta didik dengan pendidik. Tidak akan terjadi proses interaksi atau proses belajar apabila hanya ada satu unsur yaitu pendidik atau peserta didik. Kegiatan belajar dilakukan oleh siswa, dan melalui kegiatan tersebut akan nampak perubahan. Sementara kegiatan mengajar dilakukan pendidik untuk memfasilitasi proses belajar. Kedua peranan itu tidak akan terlepas dari interaksi atau proses belajar antara dua unsur untuk mencapai tujuan yang di inginkan.

Pendidikan jasmani adalah bagian integral dari kegiatan pendidikan secara keseluruhan yang bertujuan untuk meningkatkan kemampuan para siswa melalui aktivitas jasmani. Melalui pendidikan jasmani dapat di kembangkan kemampuan intelektual, kognitif, hubungan sosial, kesegaran jasmani dan mental. Dengan demikian pendidikan pendidikan jasmani bertujuan mengembangkan anak didik menuju manusia yang sehat jasmani dan rohani.

Dalam proses pembelajaran pendidikan jasmani guru harus dapat mengajarkan berbagai keterampilan gerak dalam pelajaran pendidikan jasmani.

Sepak bola adalah materi yang ada dalam pelajaran pendidikan jasmani, materi ini harus di sampaikan oleh guru.

Dari salah satu cabang olahraga, sepak bola merupakan olah raga yang banyak diminati dan digemari oleh seluruh lapisan masyarakat di dunia tidak hanya lakilaki, kaum perempuan pun banyak yang memainkan permainan sepak bola. Untuk dapat bermain sepak bola dengan baik, setiap pemain perlu menguasai teknik dasar yang baik karena dengan menguasai teknik dasar yang baik pemain tersebut cenderung bermain sepak bola dengan baik pula.

Menendang bola diartikan sebagai teknik menyentuh atau mendorong bola menggunakan bagian kaki. Menendang digunakan untuk melakukan operan dan menembak ke arah gawang untuk mencetak goll. Kaki merupakan bagian tubuh yang dominan digunakan dalam permainan sepak bola, bagian kaki yang dapat digunakan untuk menendang adalah kaki bagian dalam, punggung kaki dan kaki bagian luar. Masingmasing bagian kaki yang digunakan memiliki fungsi untuk menendang ke arah gawang dan melakukan operan.

Metode demonstrasi adalah salah satu metode mengajar yang menggunakan peragaan dalam menyampaikan suatu kegiatan dengan tujuan tertentu. Metode demonstrasi digunakan untuk memperjelas suatu pengertian atau memperlihatkan bagaimana berjalannya suatu proses. Dalam praktiknya metode demonstrasi dapat dilakukan oleh guru atau peserta didik itu sendiri. Kelebihan metode demonstrasi sendiri adalah peserta didik akan lebih terarah dan akan mengurangi perhatian kepada masalah lain pada proses pembelajaran. Metode demonstrasi dapat menambah pengalaman peserta didik dan dapat menjawab semua masalah yang timbul di dalam pikiran peserta didik karena peserta didik ikut berperan secara langsung.

Setiap metode yang digunakan dalam proses belajar mengajar memiliki kelebihan dan kelemahannya masing-masing. H. Wina Sanjaya menyatakan sebagai suatu metode pembelajaran demonstrasi memiliki bebrapa kelebihan dan kekurangan, di antaranya:

1. Melalui metode demonstrasi terjadinya verbalisme akan dapat dihindari, sebeb siswa disuruh langsung memperhatkan bahan pelajaran yang dijelaskan.

2. Proses pembelajaran akan lebih menarik, sebab siswa tidak hanya mendengar, tetapi juga melihat peristiwa yang terjadi. 


\section{METODOLOGI PENELITIAN}

Metode penelitian merupakan cara bagaimana peneliti mendapatkan sebuah data yang dapat mendukung penelitian. Metode penelitan memandu peneliti tentang urutan bagaimana penelitian itu dilakukan. Hipotesis yang telah dirumuskan perlu diuji kebenarannya. Untuk memperoleh jawaban atas rumusan hipotesis tersebut maka diperlukan suatu metodologi penelitian.

Menurut "metode penelitian pada dasarnya merupakan cara ilmiah untuk mendapatkan data dengan tujuan dan kegunaan tertentu".

Jasa Ungguh Muliawan mengungkapkan bahwa "metode penelitian adalah cara atau jalan yang ditempuh untuk melakukan suatu penelitian.

Metode penelitian merupakan suatu teknik atau prosedur untuk mengumpulkan dan menganalisa data. Terkadang metode penelitian ini disebut juga dengan desain penelitian. Apabila metode penelitian tadi disusun menjadi suatu metodologi penelitian maka ada langkah tertentu untuk mengumpulkan data dan mengolah data agar tidak terjadi kerancuan.

Berdasarkan beberapa pendapat para ahli tentang metode penelitian dapat disimpulkan bahwa metode penelitian merupakan suatu cara yang digunakan oleh peneliti untuk mendapatkan sebuah data sebagai pendukung penelitian dengan tujuan dan kegunaan tertentu. Dalam penelitian ini peneliti menggunakan metode literatur.

\section{HASIL DAN PEMBAHASAN}

A. Hasil penelitian dari data primer:

Metode mengajar adalah cara-cara yang dilakukan oleh guru/pelatih dalam menyajikan atau menampilkan suatu tujuan yang telah ditetapkan dan hendak dicapai. Terdapat berbagai macam metode yang dapat diterapkan/ di aplikasikan dalam berbagai situasi dan kondisi salah satunya adalah metode demonstrasi.
Metode demonstrasi merupakan cara menyajikan/ menampilkan suatu tujuan dengan cara memperagakan barang, aturan-aturan, kejadian suatu kegiatan baik secara langsung mau pun tidak langsung. Terdapat banyak metode yang dapat digunakan sebagai langkah strategis untuk mencapai tujuan dalm proses pembelajaran di kelas mau pun di luar kelas, metode demonstrasi dapat dilakukan dengan cara langsung memperagakan atau melalui tayangan video.

Sepak bola merupakan permainan olahraga beregu yang dimainkan oleh dua tim yang saling berhadapan, jumlah pemain tiap-tiap regu adlah 11 pemain dengan beberapa jumlah pemain cadangan lainnya, jalannya pertandingan atau permainan sepak bola yaitu 2 x 45 menit dengan 10-15 menit waktu istirahat di setiap babaknya.

Permainan sepak bola adalah permaian yang menggunakan bola yang berbentuk bulat dan terbuat dari bahan karet sebagai alatnya, kaki adalah bagian anggota tubuh yang dominan digunakan untuk menendang dalam permainan sepak bola. setiap bagian kaki memiliki tujuan atau fungsinya : kaki bagian dalam biasanya digunakan untuk mendapatkan keakuratan tendangan baik dalam operan maupun menembak bola ke arah gawang dari jarak yang dekat. Kaki bagian luar biasanya digunakan untuk melakukan operan jarak jauh, arah bola yang dihasilkan yaitu melengkung ke arah luar, punggung kaki sering digunakan oleh setiap pemain sepak bola dalam menghasilkan tendangan yang sulit untuk dibaca arah bolanya.

B. Hasil penelitian dari data sekunder:

Berdasarkan hasil penelitian dari berbagai sumber terutama sumber sekunder dalam penelitian yang menggunakan metode demonstrasi menyatakan bahwa terdapat berbagai hasil yang sangat signifikan dibandingkan dengan berbagai metode lainnya. Metode dan design penelitan yang digunakan dalam setiap penelitan dari sumber sekunder sangat beragam. Pada penelitian ini 
metode yang digunakan yaitu metode literatur dengan pendekatan kualitatif. Analisa data dilakukan dari berbagai sumber yang relevan dengan cara mengumpulkan berbagai sumber data kemudian merangkum data yang telah terkumpul yang selanjutnya menarik kesimpulan. Hasil dari penelitian ini bahwa metode demosntrasi dapat dijadikan sebagai salah satu metode dalam meningkatkan ketepatan menendang menggunakan punggung kaki pada permainan sepak bola.

\section{Pembahasan Penelitian}

Berdasarkan dari data yang telah dikumpulkan dan analisa didapatkan hasil dari beberapa sumber yang peneliti dapat disimpulkan bahwa model pembelajaran metode demonstrasi dapat memberikan pengaruh yang signifikian dan dapat dijadikan sebagai salah satu refernsi metode dalam meningkatkan keterampilan menendang menggunakan punggung kaki pada permaian sepak bola.

Metode merupakan cara atau teknik untuk melakukan sesuatu. Metode mengajar berarti cara yang dilakukan dalam melaksanakan proses pe,belajaran. Dalam pemakaian yang umum, metode diartikan sebagai suatu cara mengajar atau prosedur yang dipakai untuk mencapai tujuan tertentu. Metode demonstrasi adalah cara memperagakan barang, kejadian, aturan, dan urutan melakukan suatu kejadian. Metode demonstrasi sebagai metode belajar mengajar dapat diartikan sebagai cara menyajikan pelajaran atau memperagakan kepada siswa tentang suatu proses, baik secara langsung maupun secara tidak langsung.

Dengan metode demonstrasi dapat memperjelas sebuah teori-teori. Pada praktiknya demonstrasi dapat dilakukan oleh guru atau siswa itu sendiri. Penggunaan metode demonstrasi dapat memberikan pengalaman baru kepada siswa karena siswa ikut berperan secara langsung.

Sepak bola adalah salah satu cabang olahraga berregu yang dimainkan oleh 2 regu/tim, masing-masing regu beranggotakan
11 pemain dan beberapa pemain cadangan, bola dimainkan dengan cara di tendang untuk melakukan operan dan menembak ke arah gawang, setiap regu berusaha memasukan bola ke gawang lawan dan mempertahankan gawang sendiri dari kemasukan bola, regu yang paling banyak mencetak gol di setiap babak adalah regu yang memenangkan pertandingan.

\section{SIMPULAN}

\begin{abstract}
Berdasarkan hasil penelitian dengan metode literatur yang telah penulis laksanakan terkait dengan pengaruh metode demonstrasi terhadap ketepatan menendang menggunakan punggung kaki pada permaianan sepak bola. maka dapat ditarik beberapa kesimpulan sebagai berikut:
\end{abstract}

1. Terdapat pengaruh metode demonstrasi terhadap keterampilan bermain sepak bola peserta didik. Metode demonstrasi memberikan pengaruh yang signifikan dibandingkan dengan metode mengajar yang lain.

2. Pembelajaran metode demonstrasi meberikan peningkatan terhadap keterampilan bermain sepak bola.

3. Terdapat peningkatan ketepatan menendang ke arah gawang menggunakan metode demonstrasi.

\section{DAFTAR PUSTAKA}

Agustine, Ine. 2011. Ensiklopedia Penjaskes. Jakarta: Trans Mandiri Abadi

Arikunto, Suharsimi. 2013. Prosedur Penelitian. Jakarta: Rineka Cipta

Crisnan, Hadian. 2011. Pendidikan Jasmani Olah raga dan Kesehatan. Depok: Arya Duta

Diantama, Suarifqi. 2018. Metode Penelitian Pendidikan. Bandung: Pustaka Rahmat

Dupri, Karsa. 2012. Upaya meningkatkan kemampuan teknik dasar permaianan sepak bola dengan metode demonstrasi pada siswa kelas $v$ sdn 3 senempak. Vol I (1) : 40-45 
Fajaristian, hendra. 2014. Jurnal pendidikan Olahraga dan Kesehatan. Vol 02 (02) : 485-488

Fathurrohman, Pupuh \& Sutikno, M. Sobry. 2017. Strategi Belajar Mengajar.

Bandung: Rifika Aditama

Mukhayat. 2020. Jurnal Ilmu Keolahragaan. Vol III (1): 62

Muliawan, Jasa Ungguh. 2014. Metodologi Penelitian Pendidikan. Yogyakarta:

Gava Media

Siyoto, Sandu \& Sodik, M. Ali. 2015, Dasar Metodologi Penelitian. Yogyakarta: literasi media publishing

Sutanto, Teguh. 2016. Buku Pintar Olahraga.

Yogyakarta: Pustaka Baru

Press

Sukmadinata, Nana Syaodih. 2012. Metode Penelitian Pendidikan. Bandung:

Remaja Rosdakarya

Suherman, Bukhori. 2018. jurnal ilmiah

FKIP Universitas Subang. Vol. 4 (2) : 2580-6335

Widiastuti. 2015. Tes dan Pengukuran

Olahraga. Depok: PT Raja Grafindo Persada 